\title{
Multidirectional Pharma-Toxicological Study on Harpagophytum procumbens DC. ex Meisn.: An IBD-Focused Investigation
}

\author{
Lucia Recinella ${ }^{1}$, Annalisa Chiavaroli ${ }^{1}$, Maurizio Ronci ${ }^{2}{ }^{\circledR}$, Luigi Menghini ${ }^{1}{ }^{(0}$, Luigi Brunetti ${ }^{1}$, \\ Sheila Leone ${ }^{1}$, Bruno Tirillini ${ }^{3}$, Paola Angelini ${ }^{4}{ }^{\circ}$, Stefano Covino ${ }^{4}$, Roberto Venanzoni ${ }^{4}{ }^{\circ}$, \\ Gokhan Zengin ${ }^{5, *} \mathbb{0}$, Simonetta Di Simone ${ }^{1}$, Maria Chiara Ciferri ${ }^{1}$, Viviana di Giacomo ${ }^{1}$, \\ Amelia Cataldi ${ }^{1}$, Monica Rapino ${ }^{6}$, Valentina Di Valerio ${ }^{7}$, Giustino Orlando ${ }^{1, *}$ \\ and Claudio Ferrante ${ }^{1(1)}$ \\ 1 Department of Pharmacy, University “G. d'Annunzio" of Chieti-Pescara, 66100 Chieti, Italy; \\ lucia.recinella@unich.it (L.R.); annalisa.chiavaroli@unich.it (A.C.); luigi.menghini@unich.it (L.M.); \\ luigi.brunetti@unich.it (L.B.); sheila.leone@unich.it (S.L.); disimonesimonetta@gmail.com (S.D.S.); \\ Mariachiara.ciferri@outlook.it (M.C.C.); viviana.digiacomo@unich.it (V.d.G.); amelia.cataldi@unich.it (A.C.); \\ claudio.ferrante@unich.it (C.F.) \\ 2 Department of Medical, Oral and Biotechnological Sciences, University "G. d'Annunzio" of Chieti-Pescara, \\ 66100 Chieti, Italy; maurizio.ronci@unich.it \\ 3 Department of Biomolecular Sciences, University of Urbino, 61029 Urbino, Italy; bruno.tirillini@uniurb.it \\ 4 Department of Chemistry, Biology and Biotechnology, University of Perugia, 06100 Perugia, Italy; \\ paola.angelini@unipg.it (P.A.); stefano.covino@unipg.it (S.C.); roberto.venanzoni@unipg.it (R.V.) \\ 5 Physiology and Biochemistry Laboratory, Department of Biology, Science Faculty, Selcuk University, \\ Campus, 42103 Konya, Turkey \\ 6 Genetic Molecular Institute of CNR, Unit of Chieti, “G. d' Annunzio” University, Via dei Vestini 31, \\ 66100 Chieti-Pescara, Italy; m.rapino@unich.it \\ 7 Department of Medicine and Ageing Sciences, “G. d' Annunzio” University, Via dei Vestini 31, \\ 66100 Chieti-Pescara, Italy; valentina.divalerio@unich.it \\ * Correspondence: gokhanzengin@selcuk.edu.tr (G.Z.); giustino.orlando@unich.it (G.O.)
}

Received: 16 January 2020; Accepted: 17 February 2020; Published: 18 February 2020 updates

\begin{abstract}
In the present study, we investigated the water extract of Harpagophytum procumbens DC. ex Meisn. in an experimental model of inflammatory bowel diseases (IBDs). Additionally, a microbiological investigation was carried out to discriminate the efficacy against bacterial and fungal strains involved in IBDs. Finally, an untargeted proteomic analysis was conducted on more than one hundred colon proteins involved in tissue morphology and metabolism. The extract was effective in blunting the production of oxidative stress and inflammation, including serotonin, prostaglandins, cytokines, and transcription factors. Additionally, the extract inhibited the growth of Candida albicans and C. tropicalis. The extract was also able to exert a pro-homeostatic effect on the levels of a wide plethora of colon proteins, thus corroborating a protective effect. Conversely, the supraphysiological downregulation of cytoskeletal-related proteins involved in tissue morphology and antimicrobial barrier function suggests a warning in the use of food supplements containing H. procumbens extracts.
\end{abstract}

Keywords: Harpagophytum procumbens; IBDs; oxidative stress; inflammation; proteomic analysis

\section{Introduction}

Inflammatory bowel diseases (IBDs) are chronic, relapsing, and multifactorial pathologies of the colon, which show increased and unbalanced intestinal immune response to external stimuli [1-4]. As a consequence of this condition, colon mucosa produces numerous pro-inflammatory biomarkers, 
including reactive oxygen/nitrogen (ROS/RNS) species, prostaglandins, and cytokines, which reinforce the inflammatory status, thus causing tissue damage [4]. Currently, the first choice drugs for treating IBDs are aminosalycilates, glucocorticoids, immune-suppressants, and tumor necrosis factor (TNF) $\alpha$ inhibitors. Nevertheless, a wide plethora of patients (20-40\%) experiences the lack of efficacy or side effects, thus highlighting the urgent need of novel therapies, which could both implementing the efficacy and reducing the incidence of side effects [5]. Plant-derived extracts have long been described as possessing the capability of contrasting IBD-related oxidative stress and inflammatory pathways [6,7]. In this regard, it is of noteworthy interest to treat inflammatory conditions through home-made extracts prepared from plants traditionally used by folk populations. These extracts, especially those prepared with traditional and biocompatible solvents (water, hydroalcoholic solutions) in the forms of infusions or decoctions, could not only represent efficacious and safe treatment in the folk populations, but also represent innovative approaches for improving and valorizing local botanical resources and productive chains.

In the present study, we further deepened the protective effects of the previously described water extract of Harpagophytum procumbens DC. ex Meisn., also known as devil's claw, in an ex vivo experimental model, that is, isolated colon specimens exposed with Escherichia coli lipopolysaccharide (LPS) [8]. In particular, the water extract of H. procumbens was further assayed for the determination of plant secondary metabolites belonging to the classes of phenols and flavonoids, namely, gallic acid, resveratrol, catechin, and epicatechin, as well as the iridoid compound harpagoside. Harpagoside is considered the main responsible component of the therapeutic activity of the plant; therefore, the measurement of its extract content (not lower than $1.2 \% \mathrm{w} / \mathrm{w}$ ) represents an evaluation of the qualitative standard described in the European Pharmacopoeia (Menghini et al., 2019). In addition, we further investigated the possible mechanisms of the water extract of $H$. procumbens on multiple inflammatory and oxidative stress pathways by measuring the production of colon serotonin (5-HT), prostaglandin $(\mathrm{PG}) \mathrm{E}_{2}$, and 8-iso- $\mathrm{PGF}_{2 \alpha}$, as well as tumor necrosis factor $\alpha(\mathrm{TNF} \alpha)$, nuclear factor kappa B (NFKB), interleukin (IL)-6, and nuclear factor erythroid 2-related factor 2 (Nrf2) mRNA levels. The putative extract mechanism was also investigated through an untargeted proteomic analysis. In this regard, the proteomic investigation was carried out on a cluster of more than 100 proteins involved in colon cell morphology and metabolism. Finally, the extract antimicrobial activity was studied against E. coli, S. aureus, P. aeruginosa, Candida albicans, and C. tropicalis, which are known to be involved in IBDs [9-12].

\section{Materials and Methods}

\subsection{Pharmacognostic Studies}

\subsubsection{Plant Material and Extraction Procedure}

H. procumbens DC. ex Meisn. plant material was purchased in a local market in Namibia and authenticated by Prof. Luigi Menghini, head of the chair in Pharmaceutical Botany at the Department of Pharmacy of "G. d'Annunzio" University (Chieti, Italy). The pharmacognostic description of plant material and the preparation of the extract through ultrasound-assisted method is fully described in the Supplementary Materials section.

\subsubsection{Phytochemical Profile}

H. procumbens water extract was analyzed for its content in phenols and flavonoids through validated colorimetric methods. Total phenols and flavonoids were expressed as equivalents of gallic acid and rutin, respectively. The acid gallic, catechin, epicatechin, and resveratrol content was also evaluated through independent high performance liquid chromatography (HPLC)-fluorimetric analysis, whereas the harpagoside level was measured with HPLC-diode array (DAD) analytical methods. The antiradical activity was assessed through 1,1-diphenyl-2-picrylhydrazyl (DPPH) radical and 
$\beta$-carotene/linoleic acid assays. The detailed protocols related to analytical methods and colorimetric assays are described in published papers $[8,13,14]$ and reported in extenso in the Supplementary Materials section.

\subsection{Toxicological, Pharmacological, and Microbiological Studies}

\subsubsection{Artemia Salina Lethality Bioassay}

The cytotoxicity of $H$. procumbens extract was formerly studied with Artemia salina lethality bioassay, whose protocol is fully described in the Supplementary Materials section.

\subsubsection{Ex Vivo Studies}

Wild type (C57/BL6) male mice (2.5 months old, weight 20-22 g) were housed in plexiglas cages (2-4 animals per cage; $55 \times 33 \times 19 \mathrm{~cm}$ ) and maintained under standard laboratory conditions $\left(21 \pm 2{ }^{\circ} \mathrm{C} ; 55 \pm 5 \%\right.$ humidity) on a $14 / 10 \mathrm{~h}$ light/dark cycle, with ad libitum access to water and food, $24 \mathrm{~h} /$ day throughout the study, with no fasting periods. Mice were fed with a standard rodent chow (Prolab RMH2500, PMI Nutrition International, Brentwood, MO, USA). Housing conditions and experimentation procedures were strictly in accordance with the European Community ethical regulations (EU directive no. 63/2010) on the care of animals for scientific research. According to the recognized principles of "Replacement, Refinement and Reduction of Animals in Research", colon specimens were obtained as residual material from vehicle-treated mice randomized in our previous experiments approved by the Local Ethical Committee ('G. d'Annunzio' University, Chieti-Pescara, Italy) and Italian Health Ministry (authorization no. 885/2018-PR).

Isolated mouse colon specimens were collected and maintained in a humidified incubator with $5 \% \mathrm{CO}_{2}$ at $37^{\circ} \mathrm{C}$ for $4 \mathrm{~h}$, in RPMI buffer with added bacterial LPS $(10 \mu \mathrm{g} / \mathrm{mL})$ (incubation period), as previously reported [15]. H. procumbens extract $(100-1000 \mu \mathrm{g} / \mathrm{mL})$ and harpagoside $(12 \mu \mathrm{g} / \mathrm{mL})$ were used as pharmacological stimuli. Their efficacy was evaluated in comparison with the reference drug sulfasalazine $(2 \mu \mathrm{g} / \mathrm{mL})$. $\mathrm{PGE}_{2}$ and 8 -iso- $\mathrm{PGF}_{2 \alpha}$ levels $(\mathrm{ng} / \mathrm{mg}$ wet tissue) were measured in tissue and cell supernatants by radioimmunoassay (RIA), as previously reported [16]. Additionally, tissue homogenates were assayed for the determination of 5-HT level (ng/mg wet tissue) through HPLC coupled to electrochemical detection [17]. Individual colons were also dissected for evaluating tumor necrosis factor $\alpha(\mathrm{TNF} \alpha)$, nuclear factor kappa B (NFkB), interleukin (IL)-6, and nuclear factor erythroid 2-related factor 2 (Nrf2) gene expression, as previously reported $[15,18]$. The comparative $2^{-\Delta \Delta C t}$ method was used to quantify the relative abundance of mRNA and then determine the relative changes in individual gene expression (relative quantification) [19]. Finally, an untargeted proteomic analysis was carried out on tissue homogenate [20,21]. The detailed description of RIA, real-time PCR and mass spectroscopy analysis is reported in the Supplementary Materials section.

\subsubsection{Antimicrobial Susceptibility Testing}

In vitro antimicrobial activity of $H$. procumbens extract was assessed against three bacterial strains, namely, P. aeruginosa (ATCC 15442), E. coli (ATCC 10536), and S. aureus (ATCC 6538), and two yeasts and filamentous fungi, namely, C. albicans (YEPGA 6183) and C. tropicalis (YEPGA 6184). Voucher microbial cultures are maintained in the PeruMycA culture collection of the Department of Chemistry, Biology and Biotechnology (University of Perugia, Italy) and are available upon request. The extract activity was evaluated in comparison with reference anti-bacterial and anti-micotic drugs, namely ciprofloxacin (Sigma-Aldrich, Milan, Italy) and fluconazole (Sigma-Aldrich, Milan, Italy), respectively. The detailed protocols were described in our previous papers and are enclosed as supplementary materials [22,23]. 


\subsubsection{Human Colon Cancer HCT116 Cell Culture}

HCT116 human colon carcinoma cell line (ATCC CCL-247) was maintained in DMEM supplemented with $10 \%$ FBS and penicillin-streptomycin $(100 \mu \mathrm{g} / \mathrm{mL})$. Cells were grown at $37{ }^{\circ} \mathrm{C}$ in a humified atmosphere of $5 \% \mathrm{CO}_{2}$ and treated with $\mathrm{LPS} 10 \mu \mathrm{g} / \mathrm{mL}$ and different concentrations of $H$. procumbens water extract $(1-1000 \mu \mathrm{g} / \mathrm{mL})$. Cell viability was measured by MTT (3 [4-dimethylthiazol-2yl]-2,5-diphenyl tetrazolium bromide) growth assay as recently described [20]. Cell number was quantified by the amount of tetrazolium reduction in viable mitochondria. Cultured cells were seeded into a 96-well plate at $3 \times 103$ cells/well and treated as described above. After 24 and $48 \mathrm{~h}$, the cells were processed according to the manufacturer's instructions, and the absorbance of each sample was detected at $570 \mathrm{~nm}$. Three independent experiments were performed under the same experimental conditions.

\subsection{Statistical Analysis}

The analysis of variance (ANOVA) followed by Newman-Keuls multiple comparison test was used to evaluate the statistical significance between the pharmacological group. GraphPad Prism version 5.01 for Windows (GraphPad Software, San Diego, CA, USA) was used as statistical software in order to compare the means \pm S.D. for each experimental group. Statistical significance was set at $p<0.05$. The number of animals randomized for each experimental group was calculated on the basis of the "resource equation" $N=(\mathrm{E}+\mathrm{T}) / \mathrm{T}(10 \leq \mathrm{E} \leq 20)[24]$.

\section{Results and Discussion}

In the present study, a multidirectional investigation was carried out on the water extract from H. procumbens root subjected to an ultrasound-assisted extraction procedure at $60{ }^{\circ} \mathrm{C}$, in order to mimic the traditional home-made extraction procedure [25]. The HPLC-DAD quantitative analysis [8,13] confirmed the validity of the extraction method that, in agreement with European Pharmacopoeia, gave harpagoside yield in the range of $1.2-1.5 \%(\mathrm{w} / \mathrm{w})$. This result was also consistent with our previous study aimed at optimizing and validating the use of the $H$. procumbens water extract prepared with an automatic instrumental and scaling-up procedure [8]. The colorimetric assays also revealed the presence of total phenols and flavonoids in appreciable amounts (Table 1), whereas the HPLC-fluorimetric fingerprint analysis identified the presence of four secondary metabolites, namely, gallic acid, catechin, epicatechin, and resveratrol (Table 2), whose levels were comparable with that of harpagoside. In this regard, the antiradical/antioxidant activities shown by DPPH and $\beta$-carotene/linoleic acid assays (Table 3) are consistent with the cluster of extract secondary metabolites revealed by HPLC analyses [20,23], thus suggesting potential multiple antioxidant/anti-inflammatory mechanisms.

Table 1. Total phenols and flavonoids determined via colorimetric assays of the Harpagophytum procumbens extract.

\begin{tabular}{ccccc}
\hline \multirow{2}{*}{ Table 1} & Total Phenols & \multicolumn{3}{c}{ Total Flavonoids } \\
\cline { 2 - 5 } & $\mathbf{m g} / \mathbf{g}$ Extract & SD & mg/g Extract & SD \\
\hline H. procumbens & 65.7 & 6.9 & 5.4 & 1.9 \\
\hline
\end{tabular}

Table 2. Gallic acid, catechin, epicatechin, and resveratrol (mg/g) extract determined via HPLC-fluorimetric analysis of the $H$. procumbens extract.

\begin{tabular}{ccc}
\hline Phenolic Content of $\boldsymbol{H}$. procumbens Extract & $\mathbf{m g} / \mathbf{g}$ Extract & SD \\
\hline Gallic acid & 9.74 & 0.88 \\
\hline Catechin & 2.90 & 0.35 \\
\hline Epicatechin & 3.03 & 0.18 \\
\hline Resveratrol & 3.33 & 0.33 \\
\hline
\end{tabular}


Table 3. Intrinsic antiradical activity of $H$. procumbens extract determined via colorimetric 1,1-diphenyl-2-picrylhydrazyl (DPPH) and $\beta$-carotene/linoleic acid assays.

\begin{tabular}{ccccc}
\hline Antitadical Activity & DPPH & \multicolumn{3}{c}{$\beta$-Carotene/Linoleic Acid } \\
\hline & $\mathrm{IC}_{50} \mu \mathrm{g} / \mathrm{mL}$ & $\mathrm{SD}$ & $\mathrm{IC}_{50} \mu \mathrm{g} / \mathrm{mL}$ & $\mathrm{SD}$ \\
\hline BHT & & & 2.5 & 0.32 \\
\hline Trolox & 4.07 & 0.44 & 4.03 & 0.57 \\
\hline H. procumbens & 121.01 & 16.6 & 16.8 & 2.05 \\
\hline
\end{tabular}

The extract was also tested on brine shrimp lethality assay, in order to verify the biocompatible limits for the subsequent pharmacological investigation. The brine shrimp A. salina Leach assay revealed an $\mathrm{LC}_{50}$ value $>10 \mathrm{mg} / \mathrm{mL}$ (Figure 1), thus corroborating the concentration range of 100-1000 $\mu \mathrm{g} / \mathrm{mL}$ that was selected according to independent toxicological assays in our previous in vitro study [8]. The protective effects of the $H$. procumbens water extract $(100-1000 \mu \mathrm{g} / \mathrm{mL}$ ) was also evaluated on isolated mouse colon specimens exposed to LPS, in order to reproduce the burden of inflammation and oxidative stress occurring in ulcerative colitis, in vivo [26]. In particular, the extract effects were evaluated against the increased levels of pro-inflammatory and pro-oxidant colon mediators, including 5-HT, PGE 2 , and 8-iso-PGF $2 \alpha$. The mRNA levels of TNF $\alpha$, IL-6, NFkB, and Nrf2 were measured, as well. As depicted in Figures 2-4, the extract was able to blunt the LPS-induced level of 5-HT, $\mathrm{PGE}_{2}$, and 8-iso-PGF $2 \alpha$ in a concentration-independent manner. Additionally, the blunting effect was comparable to those exerted by both harpagoside $(12 \mu \mathrm{g} / \mathrm{mL})$ and sulfasalazine $(2 \mu \mathrm{g} / \mathrm{mL})$ used as the reference standard and drug, respectively. In particular, the employed concentration of harpagoside reflects its amount in the pharmacological group treated with the highest tested concentration of the extract $(1000 \mu \mathrm{g} / \mathrm{mL})$. In analogy, the extract exerted a concentration-independent inhibition of TNF $\alpha$, IL-6, and NFKB gene expression (Figures 5-7). Also in this case, the efficacy was comparable to those of harpagoside and sulfasalazine, whereas the extract was ineffective in reducing LPS-induced Nrf2 gene expression (Figure 8). Collectively, besides being in agreement with our previous study [8], the actual results suggest that the anti-oxidant and anti-inflammatory effects could not only be ascribed to the sole extract harpagoside content, but, albeit in part, to the other identified secondary metabolites. Particularly, the presence of gallic acid, catechin, epicatechin, and resveratrol is consistent with the reduced levels of the selected pro-oxidant/pro-inflammatory biomarkers [27-29]. Previously, Fiebich and colleagues [30] suggested that the anti-inflammatory $H$. procumbens activity could occur via the inhibition of the activator protein-1 (AP-1) transcription factor, without any involvement of NFKB and mitogen-activated protein kinase (MAPK) pathways. Nevertheless, the total phenolic and flavonoid content found in the extract could account for a possible involvement of both NFKB and MAPK pathways $[27,29,31]$. In this regard, our finding of reduced $N_{k} B$ gene expression following extract treatment further supports the modulatory effect on multiple pathways controlling oxidative stress and inflammatory response. Actually, these discrepancies could be related, at least in part, to the differences in polarity and chemical composition between the described $H$. procumbens water extract and the hydroalcoholic (60\% v/v) extract tested in Fiebich's study. The water extract was also assayed against bacterial and fungal strains involved in colon inflammation, including E. coli, P. aeruginosa, S. aureus, C. albicans, and C. tropicalis. Microbiome dysbiosis, a pathological condition characterized by decreased colon concentration of beneficial Firmicutes, Bacteroidetes, Actinobacteria, and Verrucomicrobia, with a concomitant increase of pathogen bacteria belonging to Enterobacteraceae, was found to be deeply related to colon inflammation [32], despite there still being no identification of causative relationship. Conversely, multiple studies suggested the involvement of pathogens such as adherent-invasive E. coli, P. aeruginosa, and S. aureus $[9,10,33]$. A pivotal role in colon inflammation could be also played by $C$. albicans and C. tropicalis, whose presence in colonic mucosa could aggravate colitis clinical symptoms [11,12]. The antimicrobial assays demonstrated that the water extract of $H$. procumbens was completely ineffective against the tested bacterial strains (Table 4). This result was not surprising and 
was in agreement with previous papers investigating the potential anti-microbial activity of water and alcoholic H. procumbens extracts [34,35]. Conversely, the anti-micotic activity (Table 5), particularly against $C$. tropicalis, is of noteworthy interest and suggests the potential use of this extract against the opportunistic fungal infections occurring in ulcerative colitis [11]. Actually, the inhibitory activity on these fungal strains could be related, at least in part, to the total phenolic and flavonoid content of this extract [36-38].

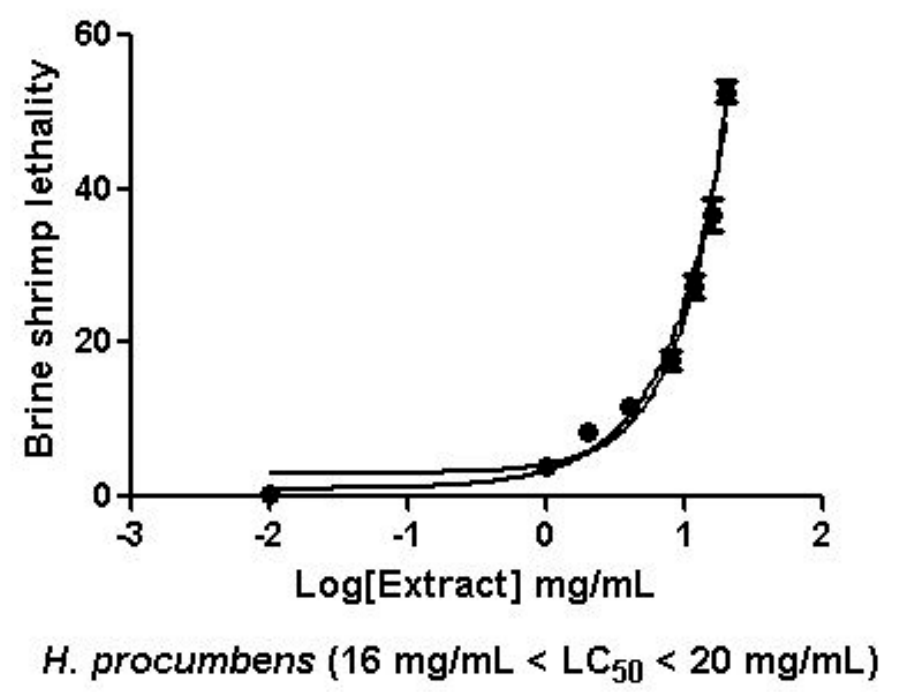

Figure 1. Effects of water H. procumbens extracts $(0.1-20 \mathrm{mg} / \mathrm{mL})$ on Artemia salina Leach viability (brine shrimp lethality test). Data are means \pm SD of three experiments performed in triplicate.

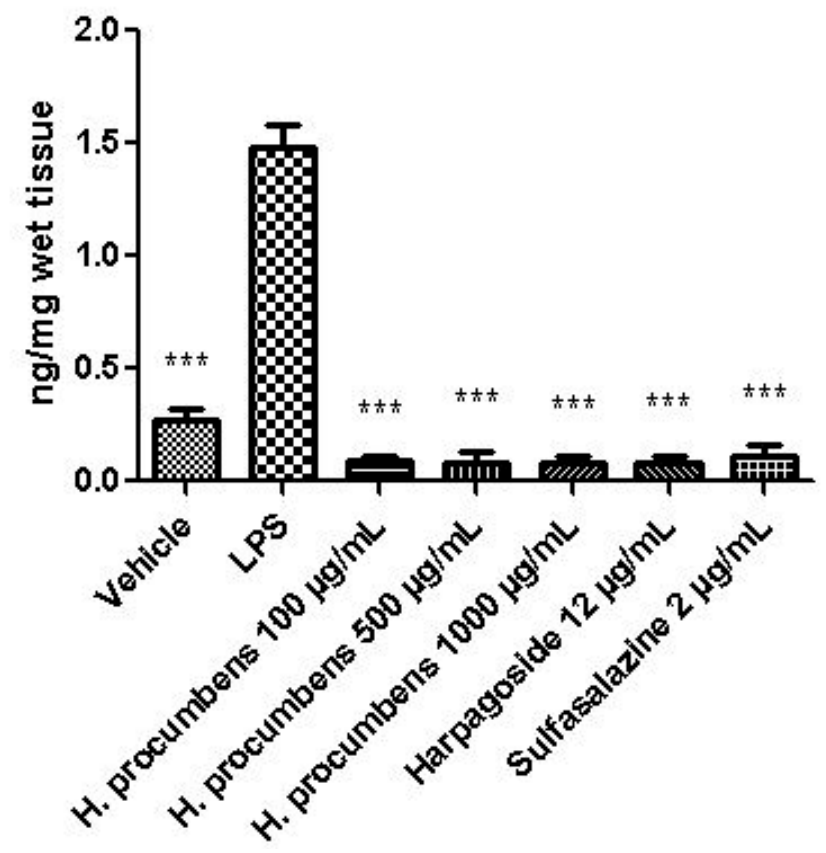

Figure 2. Effect of water $H$. procumbens extract $(100-1000 \mu \mathrm{g} / \mathrm{mL})$ on serotonin $(5-\mathrm{HT})$ level (ng/mg wet tissue) in mouse colon specimens challenged with lipopolysaccharide (LPS). ANOVA, $p<0.0001$; post-hoc, ${ }^{* * *} p<0.001$ vs. LPS. 


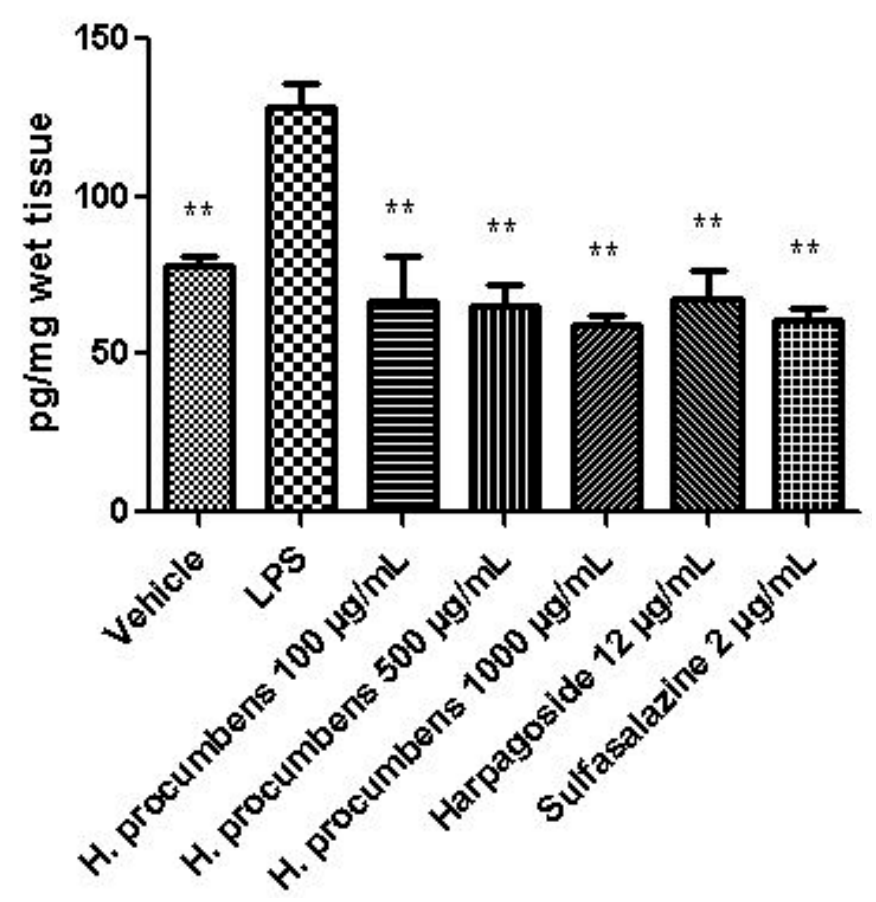

Figure 3. Effect of water $H$. procumbens extract $(100-1000 \mu \mathrm{g} / \mathrm{mL})$ on prostaglandin $(\mathrm{PG}) \mathrm{E}_{2}$ level (pg/mg wet tissue) in mouse colon specimens challenged with LPS. ANOVA, $p<0.001$; post-hoc, ${ }^{* *} p<0.01$ vs. LPS.

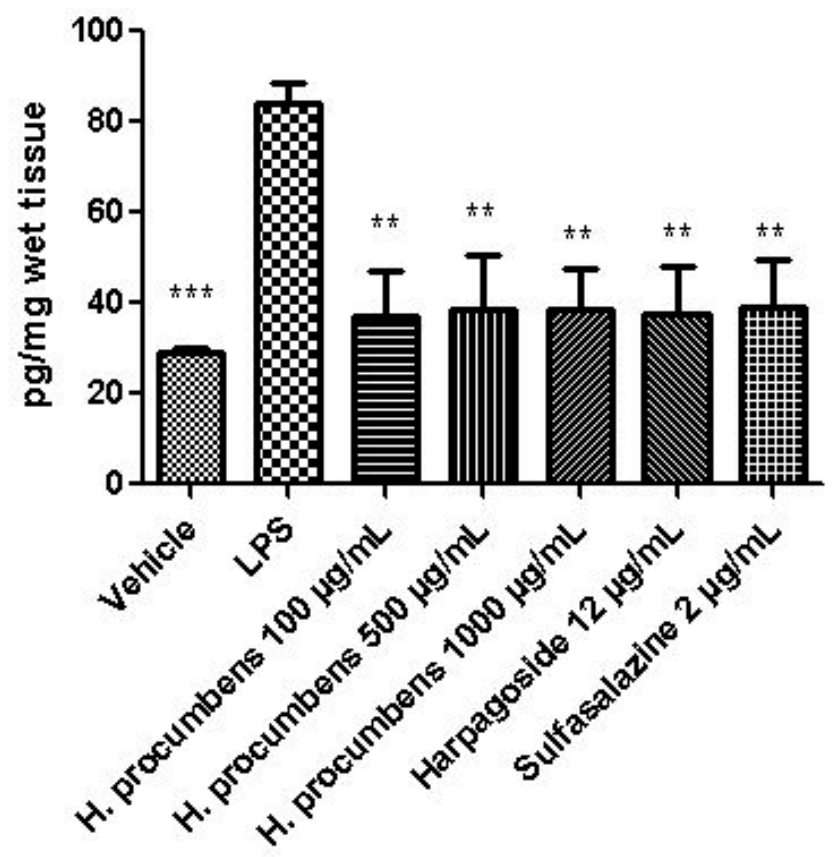

Figure 4. Effect of water $H$. procumbens extract $(100-1000 \mu \mathrm{g} / \mathrm{mL})$ on 8-iso-prostaglandin $(\mathrm{PG}) \mathrm{F}_{2 \alpha}$ level (pg/mg wet tissue) in mouse colon specimens challenged with LPS. ANOVA, $p<0.001$; post-hoc, ${ }^{* *} p<0.01,{ }^{* * *} p<0.001$ vs. LPS. 


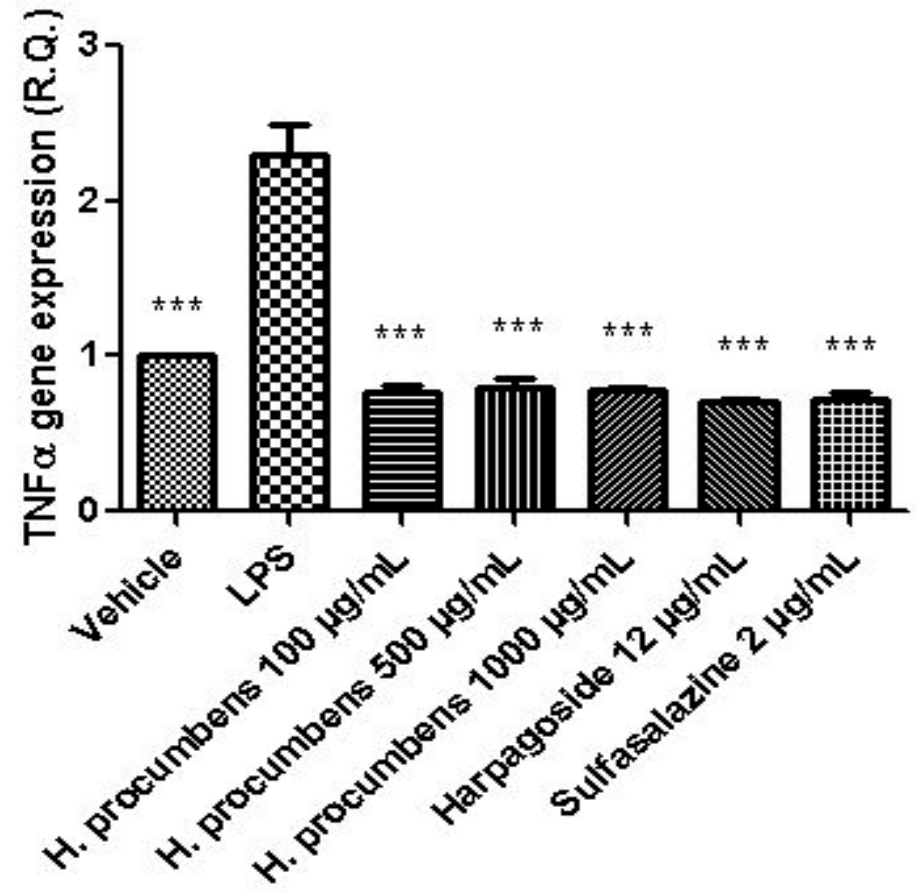

Figure 5. Effect of water $H$. procumbens extract $(100-1000 \mu \mathrm{g} / \mathrm{mL})$ on tumor necrosis factor (TNF) $\alpha$ gene expression (relative quantification) in mouse colon specimens challenged with LPS. ANOVA, $p<0.001$; post-hoc, ${ }^{* * *} p<0.001$ vs. LPS.

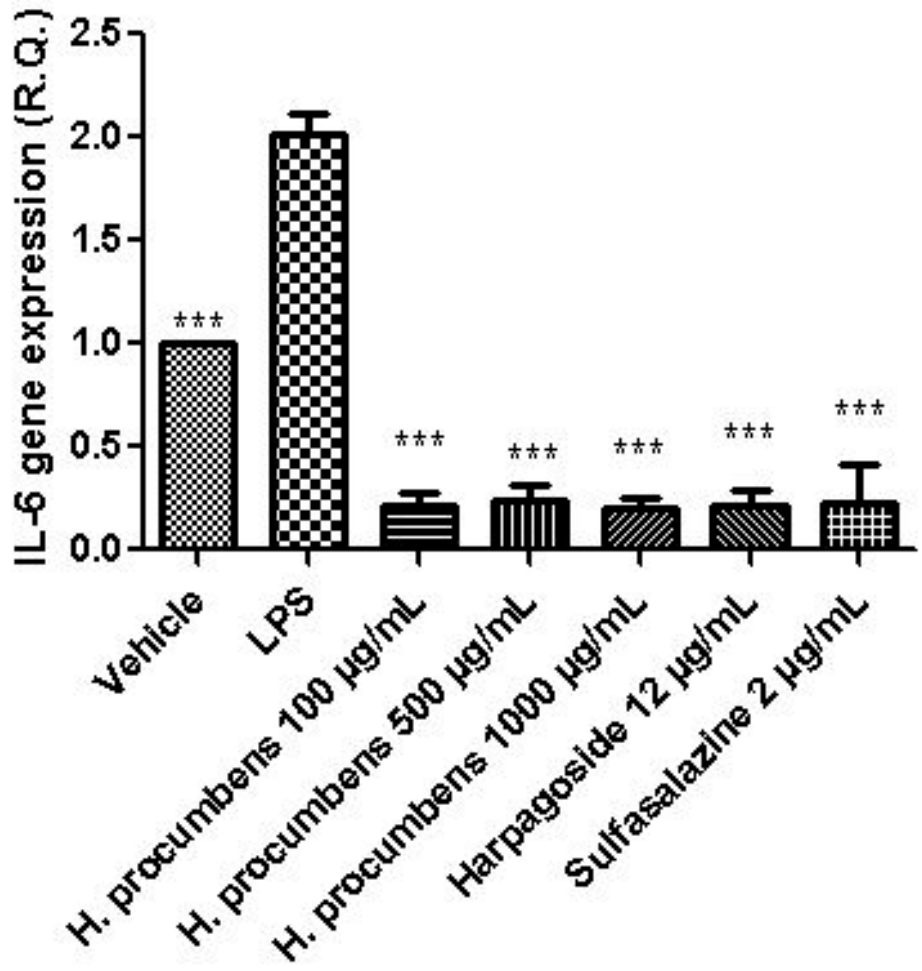

Figure 6. Effect of water H. procumbens extract (100-1000 $\mu \mathrm{g} / \mathrm{mL})$ on interleukin (IL)-6 gene expression (relative quantification) in mouse colon specimens challenged with LPS. ANOVA, $p<0.001$; post-hoc, $* * * p<0.001$ vs. LPS. 


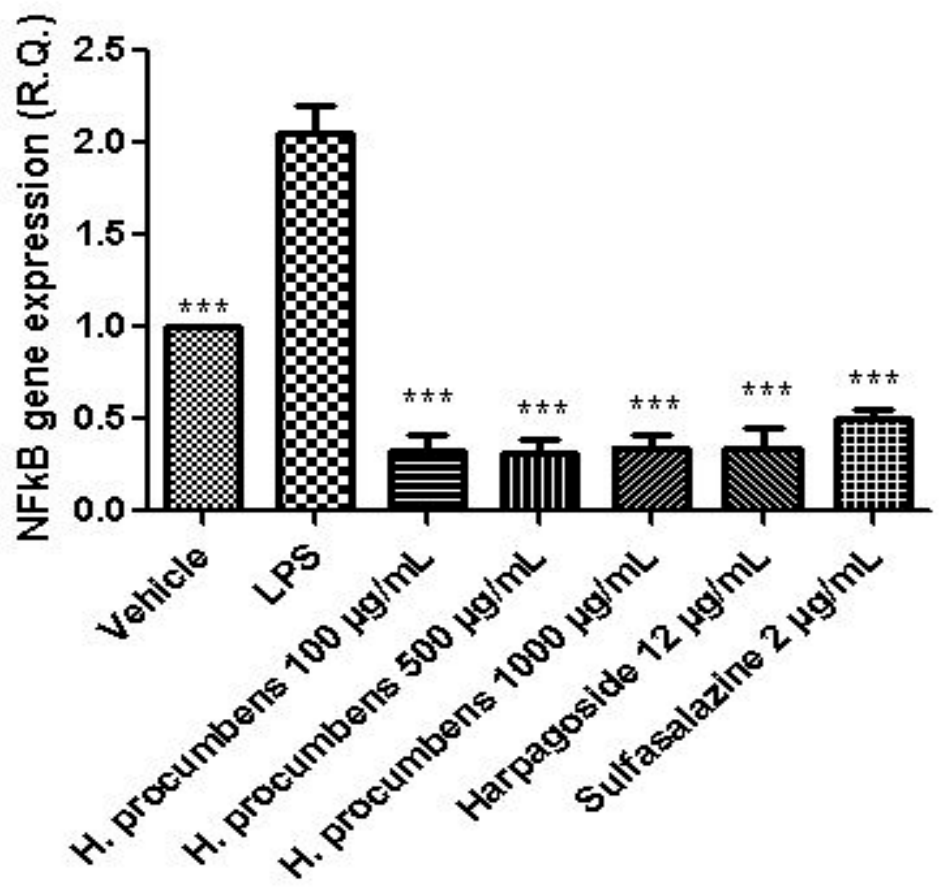

Figure 7. Effect of water $H$. procumbens extract $(100-1000 \mu \mathrm{g} / \mathrm{mL})$ on nuclear factor kappa B (NFkB) gene expression (relative quantification) in mouse colon specimens challenged with LPS. ANOVA, $p<0.001$; post-hoc, ${ }^{* * *} p<0.001$ vs. LPS.

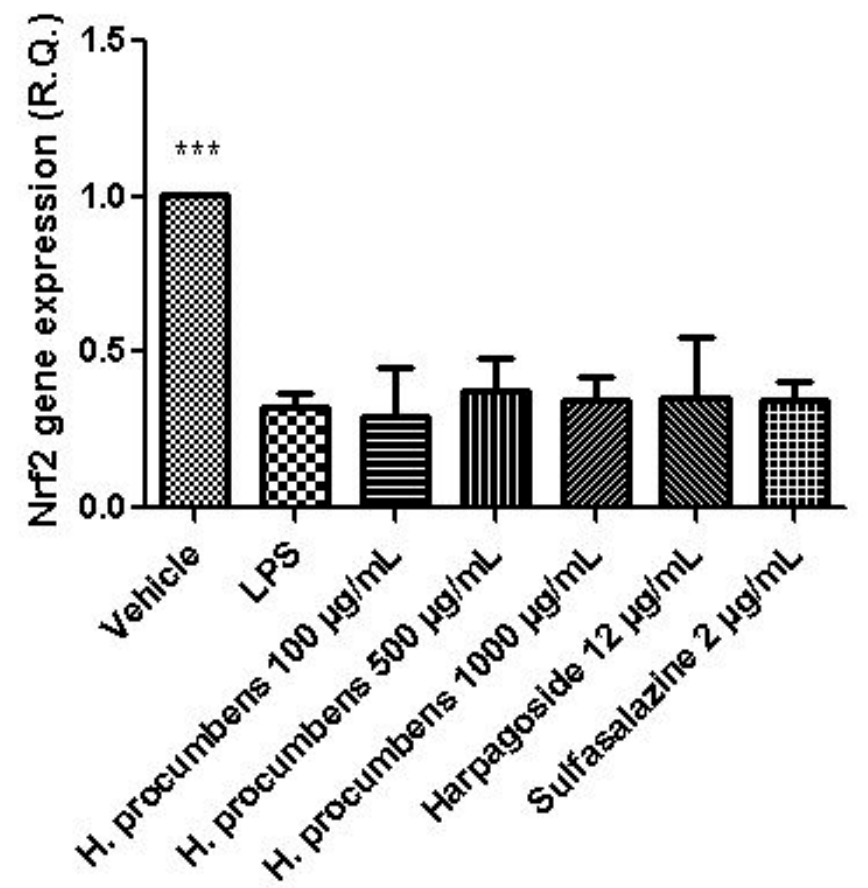

Figure 8. Effect of water H. procumbens extract $(100-1000 \mu \mathrm{g} / \mathrm{mL})$ on nuclear factor erythroid 2-related factor 2 (Nrf2) gene expression (relative quantification) in mouse colon specimens challenged with LPS. ANOVA, $p<0.001$; post-hoc, ${ }^{* * *} p<0.001$ vs. LPS. 
Table 4. Antibacterial activity exerted by H. procumbens extract on Escherichia coli, Pseudomonas aeruginosa, and Staphylococcus aureus. * MIC values are reported as geometric means of three independent replicates $(n=3)$; MIC range concentrations are reported within brackets.

\begin{tabular}{ccc}
\hline \multirow{2}{*}{ Table 4} & MIC $(\mu \mathrm{g} / \mathrm{mL})^{*}$ & \\
\cline { 2 - 3 } & H. procumbens & Ciprofloxacin \\
\hline E. coli (clinical isolate) & $11.80(9.37-18.75)$ & $<0.12$ \\
\hline P. aeruginosa (clinical isolate) & $188.98(150-300)$ & $<0.12$ \\
\hline S. aureus (ATCC 6538) & $>300$ & 0.98 \\
\hline
\end{tabular}

Table 5. Antimicotic activity exerted by H. procumbens extract on Candida albicans and Candida tropicalis. * MIC values are reported as geometric means of three independent replicates $(n=3)$; MIC range concentrations are reported within brackets.

\begin{tabular}{ccc}
\hline \multirow{2}{*}{ Table 5 } & MIC $(\mu \mathrm{g} / \mathrm{mL})^{*}$ & \\
\cline { 2 - 3 } & H. procumbens & Fluconazole \\
\hline C. albicans (YEPGA 6183) & $11.80(9.37-18.75)$ & 2 \\
\hline C. tropicalis (YEPGA 6184) & $5.89(4.68-9.37)$ & 4 \\
\hline
\end{tabular}

An untargeted and validated proteomic analysis [20,39] was also performed in order to not only deepen our knowledge about the protective effects exerted by $H$. procumbens water extract, but also to identify and/or predict potential and unknown collateral/adverse effects. In a second set of experiments conducted on colon specimens challenged with LPS, we evaluated the effect of the extract, tested at the highest concentration $(1000 \mu \mathrm{g} / \mathrm{mL})$, on the level of a wide plethora of colon proteins $(N>100)$. The levels of the identified proteins were expressed relative to the LPS group (positive control) and are depicted in Figure 9. In the figure, the green bar indicates a down-regulating effect compared to LPS, whereas the red bar indicates an up-regulating effect. It was observed that extract treatment showed the ability to exert a pro-homeostatic effect on most of the quantified proteins. In particular, the extract blunted the alteration of protein level induced by LPS, thus restoring the physiological condition observed in the vehicle-treated group. Of note are the pro-homeostatic effect on the levels of peroxiredoxin-2 (PRDX2), glutathione reductase (GSHR), catalase (CATA), and superoxide dismutase (SODC), which are deeply involved in contrasting oxidative stress-induced organ injury $[40,41]$. In addition, the water extract of $H$. procumbens normalized the levels of specific proteins, namely, drebrin-like protein (DBNL), macrophage-capping protein (CAPG), prothymosin alpha (PTMA), and high mobility group protein B2 (HGMB2), which are involved in the anti-proliferative effect, T-cell regulation, and defense against opportunistic infections [42-45]. Collectively, the pro-homeostatic effect exerted by the extract on the selected proteins is consistent with the reported anti-radical/anti-oxidant, anti-inflammatory, and anti-micotic effects. Moreover, considering the involvement of CAPG in the colon cancer progression [45], the present proteomic analysis further corroborates the anti-proliferative effect exerted by $H$. procumbens water extract $(1000 \mu \mathrm{g} / \mathrm{mL})$ on the human colon cancer HCT116 cell line [8]. On the other hand, the tested extract was ineffective against a limited number $(n=4)$ of proteins, whereas it determined a supra-physiological alteration of about 30 proteins, whose levels were not modified by the LPS stimulus. In particular, our attention focused on a group of proteins, namely ezrin (EZRI), actin-related protein 2/3 complex subunit 4 (ARPC4), plastin-1 (PLSI), and smoothelin (SMTN), which are involved in tissue morphology through multiple regulatory functions on cytoskeletal formation [46-48]. The supra-physiological alteration of protein level exerted by extract treatment could be at the basis of potential morphological alterations of colon tissue. Additionally, the extract was able to reduce the physiological concentration of colon $\alpha$-defensin 8 (DEFA8) and $\alpha$-defensin 11 (DEFA11). According to the putative role exerted by DEFA8 and DEFA11 in improving the function of the intestinal antimicrobial barrier (data reported in 
the recognized database "uniprot.org"), the supra-physiological downregulation of their levels after extract challenging could paradoxically lead to the onset of favorable conditions for the development of opportunistic pathogens, thus contrasting the observed intrinsic anti-microbial effects.

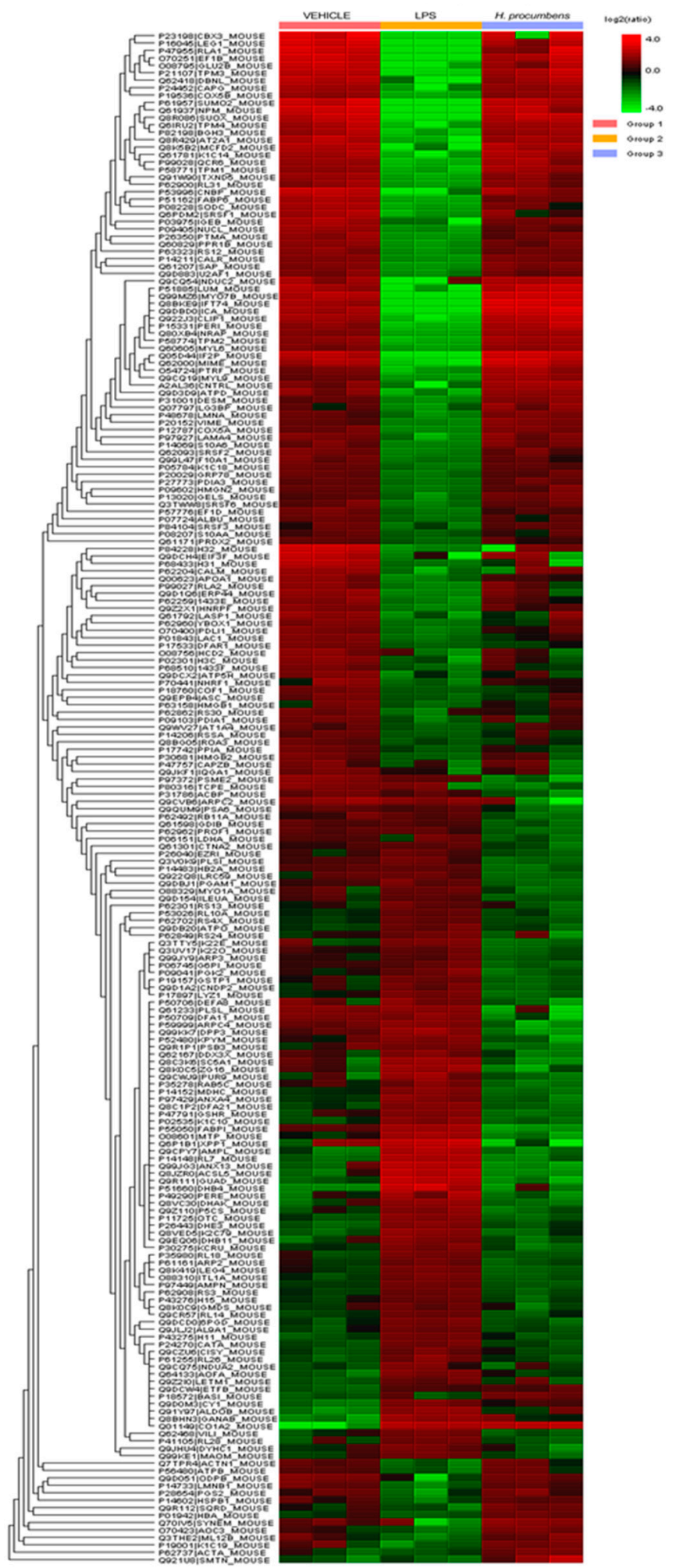

Figure 9. Untargeted proteomic analysis showing the effects of water H. procumbens extract $(1000 \mu \mathrm{g} / \mathrm{mL})$ on mouse colon specimens challenged with LPS. The activity of the detected proteins was calculated in comparison with the calibrator of the experiment (LPS group). In the figure, the green bar indicates a down-regulating effect compared to LPS, whereas the red bar indicates an up-regulating effect. 
Finally, the concentration-response relationship was further investigated by challenging the HCT116 cells with the $H$. procumbens water extract at a wider concentration range $(1-1000 \mu \mathrm{g} / \mathrm{mL})$, compared to the aforementioned ex vivo tests. In this regard, the viability of HCT116 cells was evaluated in pro-inflammatory conditions at different time points $(24-48 \mathrm{~h})$. The treatment with LPS did not show cytotoxicity after $24 \mathrm{~h}$, whereas it induced a decrease in cell viability after $48 \mathrm{~h}$ (Figure 10). On the other hand, the exposure to the highest concentration of $H$. procumbens water extract $(1000 \mu \mathrm{g} / \mathrm{mL})$ resulted in a decreased cell viability at both the experimental times. Furthermore, the release of $\mathrm{PGE}_{2}$ and 8-iso-PGF $2 \alpha$ was assessed. The results also showed a concentration-dependent inhibition of $\mathrm{PGE}_{2}$ and 8-iso-PGF $2 \alpha$ extracellular levels (Figures 11 and 12). These results agreed with the antioxidant/anti-inflammatory effects observed in isolated colons, whereas the differences in the concentration-response relationship could have been due to different employed experimental models. In this regard, it is also noteworthy to highlight the efficacy of $H$. procumbens water extract in inhibiting hydrogen peroxide-induced ROS production from HCT116 cells, in a concentration-dependent manner, whereas the inhibition of cell viability, in basal condition, was significant at the highest tested concentration [8]. Overall, we hypothesize that HCT116 cells are more sensitive to the antioxidant/anti-inflammatory effects of the extract compared to isolated tissues, thus suggesting further research in order to explore potential chemo-preventive effects in colon cancer.

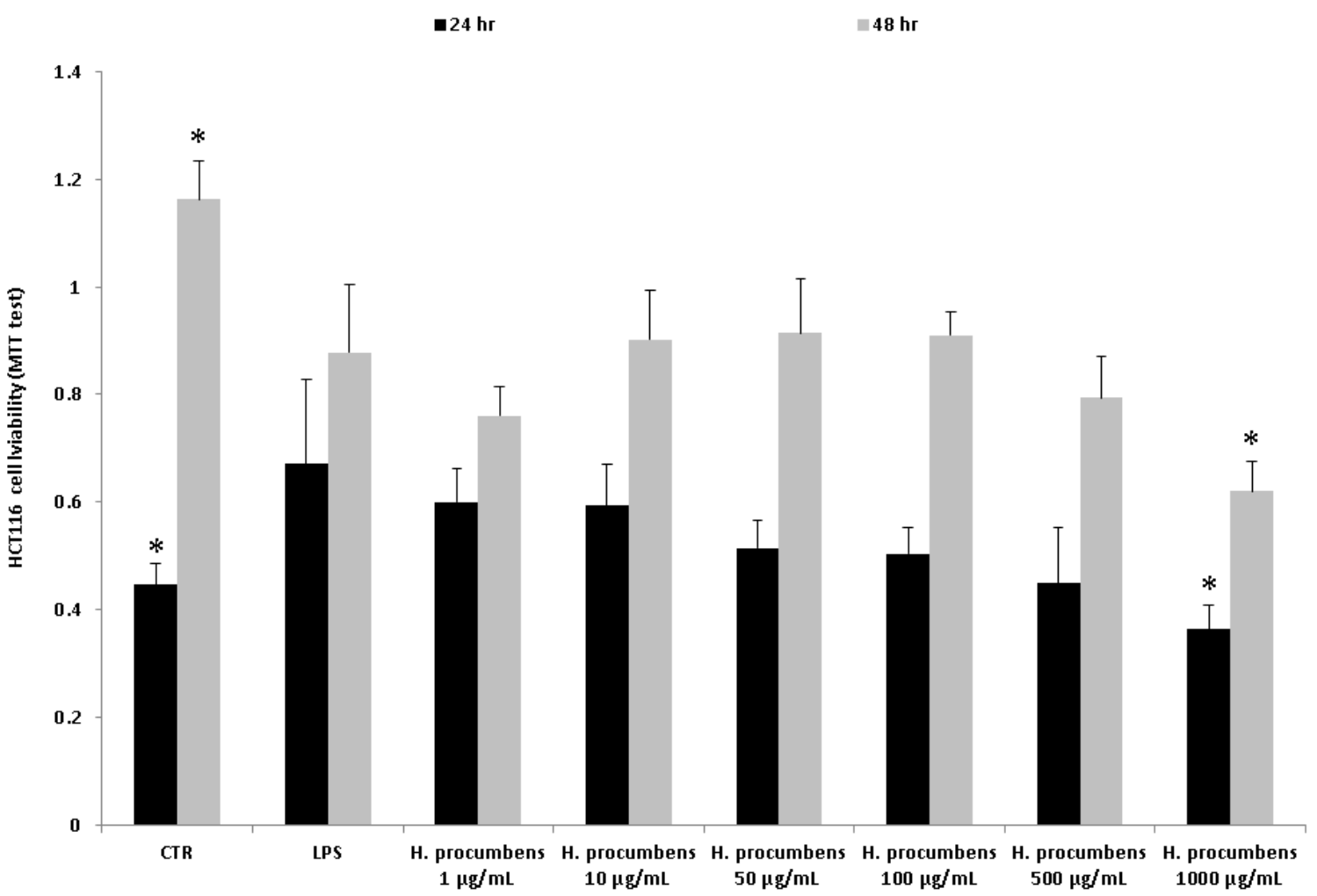

Figure 10. MTT assay of HCT116 human colon carcinoma cell line exposed to LPS $10 \mu \mathrm{g} / \mathrm{mL}$ and different concentrations $(1-1000 \mu \mathrm{g} / \mathrm{mL})$ of $H$. procumbens water extract for 24 and $48 \mathrm{~h}$. ANOVA, $p<0.01$; post-hoc, ${ }^{*} p<0.05$ vs. LPS. 


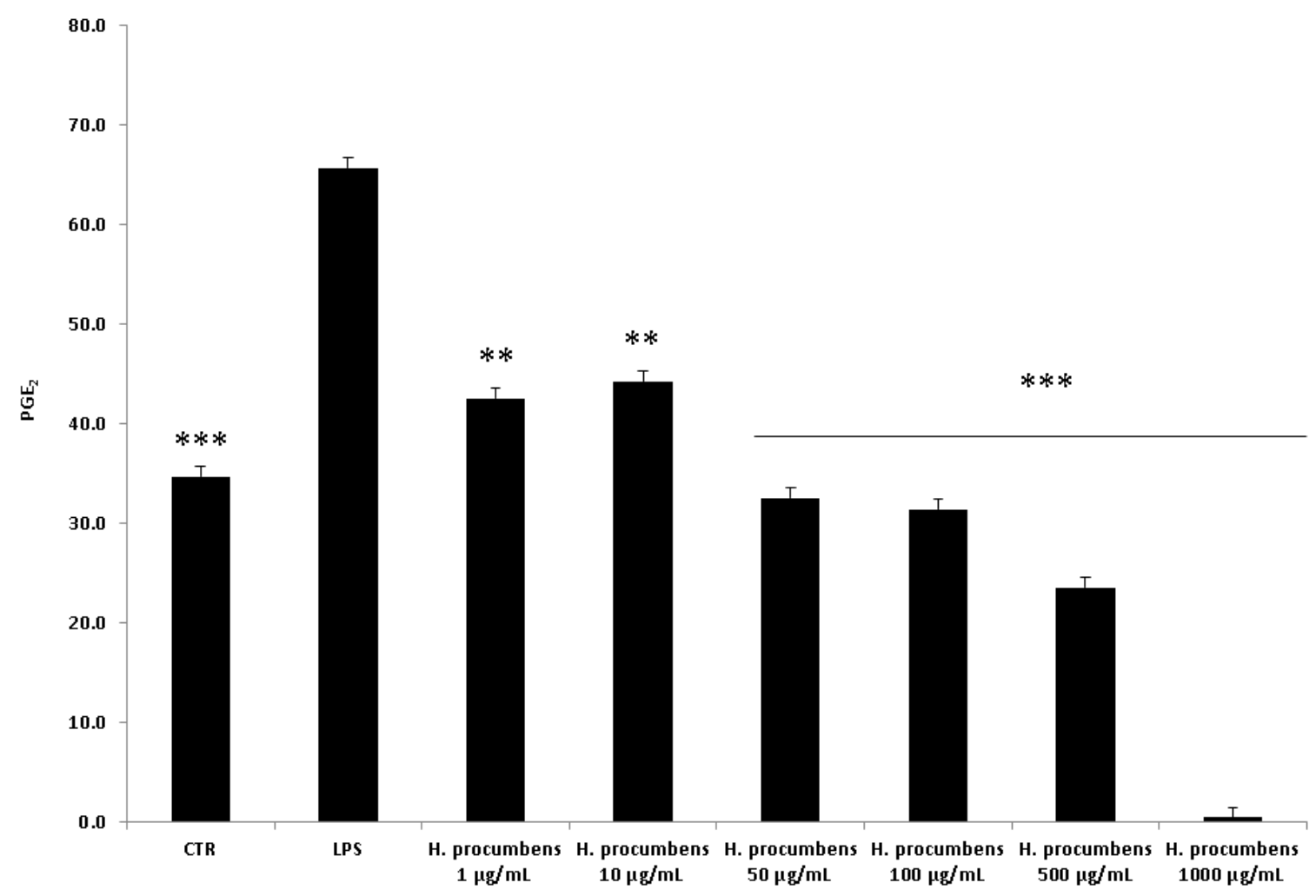

Figure 11. Effect of water $H$. procumbens extract $(1-1000 \mu \mathrm{g} / \mathrm{mL})$ on prostaglandin $(\mathrm{PG}) \mathrm{E}_{2}$ level $(\mathrm{pg} / \mathrm{mL})$ in human colon HCT116 cells challenged with LPS. ANOVA, $p<0.0001$; post-hoc, ${ }^{* *} p<0.01,{ }^{* * *} p<0.001$ vs. LPS.

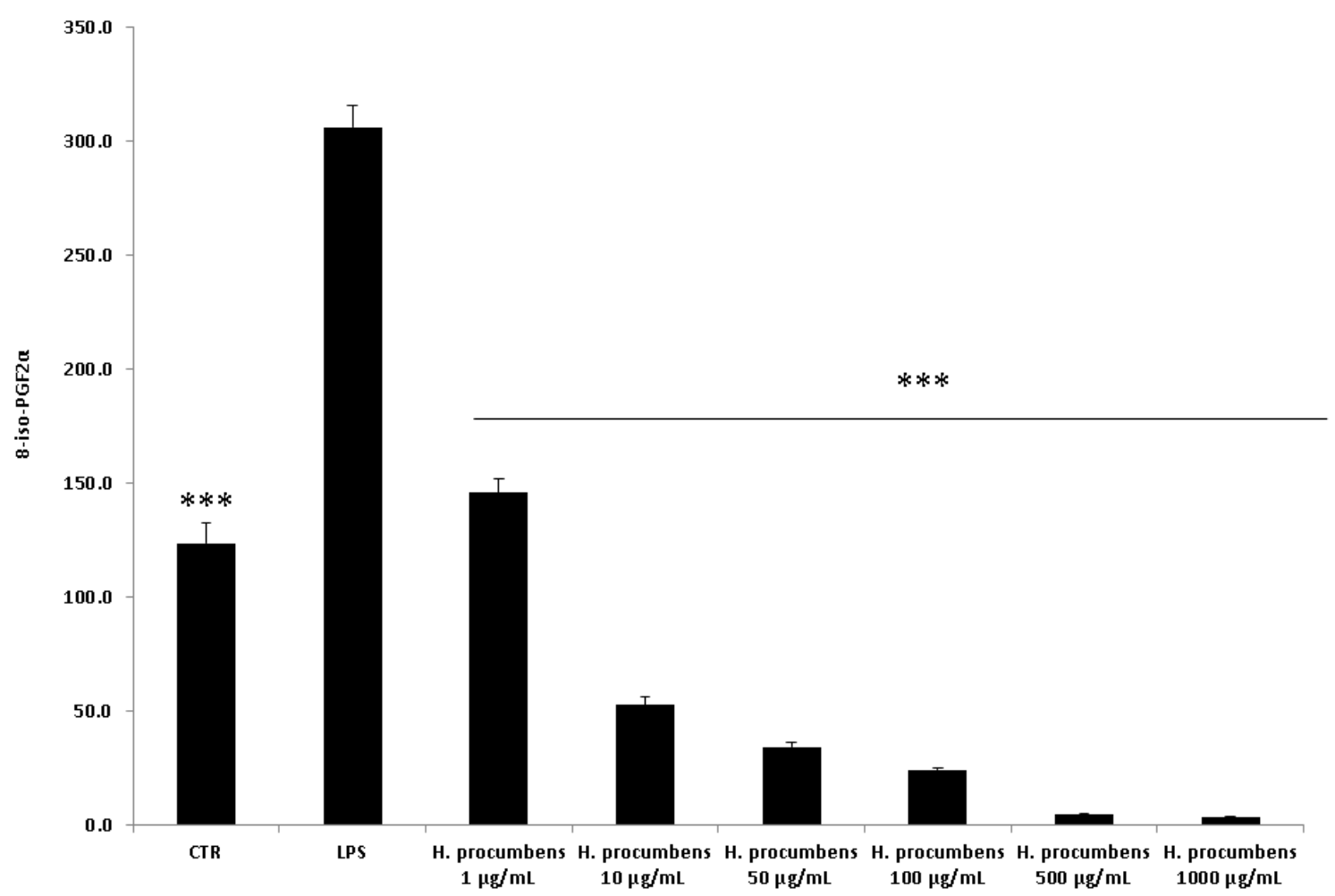

Figure 12. Effect of water H. procumbens extract $(1-1000 \mu \mathrm{g} / \mathrm{mL})$ on 8 -iso-prostaglandin (PG) $\mathrm{F}_{2 \alpha}$ level $(\mathrm{pg} / \mathrm{mL})$ in human colon HCT116 cells challenged with LPS. ANOVA, $p<0.0001$; post-hoc, ${ }^{* * *} p<0.001$ vs. LPS. 


\section{Conclusions}

In conclusion, the present multidirectional study showed protective effects of $H$. procumbens water extract in reducing the burden of oxidative stress and inflammation in LPS-stimulated colon and HCT116 cells. Anti-microbial effects against pathogen fungal strains involved in IBDs were observed, as well. Additionally, the fingerprint phytochemical analyses suggested the involvement of multiple active principles, namely harpagoside, gallic acid, catechin, epicatechin and resveratrol in the observed pharmacological effects. Nevertheless, the supra-physiological downregulation of EZRI, ARPC4, PLSI, SMTN, DEFA8, and DEFA11 after extract treatment indicated potential morphological alterations in the colon tissue that should be taken in account in further researches. In this context, the present study recommends caution in the use of botanicals containing $H$. procumbens.

Supplementary Materials: The following are available online at http://www.mdpi.com/2076-3921/9/2/168/s1, Supplementary Materials.

Author Contributions: Conceptualization, C.F., G.O., L.M.; methodology, C.F., V.d.G., L.R., A.C. (Annalisa Chiavaroli), M.R., G.Z., software, A.C. (Annalisa Chiavaroli); validation, M.R.; formal analysis, L.R., A.C. (Annalisa Chiavaroli); investigation, L.R., A.C. (Annalisa Chiavaroli), M.R., S.L., B.T., P.A., S.C., R.V., M.R., V.D.V., S.D.S., M.C.C.; resources, L.R., C.F.; data curation, C.F., L.R., A.C. (Annalisa Chiavaroli); writing-original draft preparation, C.F., L.R., G.O.; writing-review and editing, C.F., G.Z., L.M., G.O.; visualization, L.B., A.C. (Amelia Cataldi), V.d.G., G.Z.; supervision, L.B., A.C. (Amelia Cataldi), V.d.G., G.Z.; project administration, L.M., G.O., C.F.; funding acquisition, L.R., G.O., A.C. (Annalisa Chiavaroli), C.F. All authors have read and agreed to the published version of the manuscript.

Funding: This work was supported by grants from the Italian Ministry of University (FAR 2019 granted to Claudio Ferrante; FAR 2019 granted to Annalisa Chiavaroli; FAR 2019 granted to Luigi Menghini; FAR 2019 granted to Giustino Orlando; FAR 2014 granted to Lucia Recinella).

Conflicts of Interest: The authors declare no conflict of interest.

\section{Abbreviations}

$\begin{array}{ll}\text { ARPC4 } & \text { actin-related protein 2/3 complex subunit 4 } \\ \text { BHT } & \text { butylated hydroxytoluene } \\ \text { CAPG } & \text { macrophage-capping protein } \\ \text { CATA } & \text { catalase } \\ \text { DBNL } & \text { drebrin-like protein } \\ \text { DEFA8 } & \alpha \text {-defensin } 8 \\ \text { DEFA11 } & \alpha \text {-defensin 11 } \\ \text { DPPH } & \text { 1,1-diphenyl-2-picrylhydrazyl } \\ \text { EZRI } & \text { proteins namely ezrin } \\ \text { GSHR } & \text { glutathione reductase } \\ \text { HGMB2 } & \text { high mobility group protein B2 } \\ \text { 5-HT } & \text { 5-hydroxytryptamine, serotonin } \\ \text { IBDs } & \text { inflammatory bowel diseases } \\ \text { IL-6 } & \text { interleukin-6 } \\ \text { LPS } & \text { lipopolysaccharide } \\ \text { NFKB } & \text { nuclear factor kappa B } \\ \text { Nrf2 } & \text { nuclear factor erythroid 2-related factor 2 } \\ \text { PGE } 2 & \text { prostaglandin E } 2 \\ \text { 8-iso-PGF } 2 \alpha & \text { 8-iso-prostaglandin-F } 2 \alpha \\ \text { PLSI } & \text { plastin-1 } \\ \text { PRDX2 } & \text { peroxiredoxin-2 } \\ \text { PTMA } & \text { prothymosin alpha } \\ \text { ROS/RNS } & \text { reactive oxygen/nitrogen species } \\ \text { SMTN } & \text { smoothelin } \\ \text { SODC } & \text { superoxide dismutase } \\ \text { TNF } \alpha & \text { tumor necrosis factor } \alpha\end{array}$




\section{References}

1. Achitei, D.; Ciobica, A.; Balan, G.; Gologan, E.; Stanciu, C.; Stefanescu, G. Different profile of peripheral antioxidant enzymes and lipid peroxidation in active and non-active inflammatory bowel disease patients. Dig. Dis. Sci. 2013, 58, 1244-1249. [CrossRef] [PubMed]

2. Koutroubakis, I.E.; Malliaraki, N.; Dimoulios, P.D.; Karmiris, K.; Castanas, E.; Kouroumalis, E.A. Decreased total and corrected antioxidant capacity in patients with inflammatory bowel disease. Dig. Dis. Sci. 2004, 49, 1433-1437. [CrossRef] [PubMed]

3. Rezaie, A.; Parker, R.D.; Abdollahi, M. Oxidative stress and pathogenesis of inflammatory bowel disease: An epiphenomenon or the cause? Dig. Dis. Sci. 2007, 52, 2015-2021. [CrossRef] [PubMed]

4. Strober, W.; Fuss, I.; Mannon, P. The fundamental basis of inflammatory bowel disease. J. Clin. Investig. 2007, 117, 514-521. [CrossRef]

5. Choi, C.H.; Moon, W.; Kim, Y.S.; Kim, E.S.; Lee, B.-I.; Jung, Y.; Yoon, Y.S.; Lee, H.; Park, D.I.; Han, D.S. Second Korean guidelines for the management of ulcerative colitis. Intest. Res. 2017, 15, 7. [CrossRef]

6. Chung, H.-L.; Yue, G.G.-L.; To, K.-F.; Su, Y.-L.; Huang, Y.; Ko, W.-H. Effect of Scutellariae Radix extract on experimental dextran-sulfate sodium-induced colitis in rats. World J. Gastroenterol. WJG 2007, 13, 5605. [CrossRef]

7. Lenoir, L.; Joubert-Zakeyh, J.; Texier, O.; Lamaison, J.L.; Vasson, M.P.; Felgines, C. Aloysia triphylla infusion protects rats against dextran sulfate sodium-induced colonic damage. J. Sci. Food Agric. 2012, 92, 1570-1572. [CrossRef]

8. Locatelli, M.; Ferrante, C.; Carradori, S.; Secci, D.; Leporini, L.; Chiavaroli, A.; Leone, S.; Recinella, L.; Orlando, G.; Martinotti, S. Optimization of aqueous extraction and biological activity of Harpagophytum procumbens root on ex vivo rat colon inflammatory model. Phytother. Res. 2017, 31, 937-944. [CrossRef]

9. Bettenworth, D.; Nowacki, T.M.; Friedrich, A.; Becker, K.; Wessling, J.; Heidemann, J. Crohn's disease complicated by intestinal infection with methicillin-resistant Staphylococcus aureus. World J. Gastroenterol. WJG 2013, 19, 4418. [CrossRef]

10. Iguidbashian, J.P.; Parekh, J.D.; Kukrety, S.; Andukuri, V.G. Campylobacter jejuni and Pseudomonas coinfection in the setting of ulcerative colitis. Case Rep. 2018, 2018, bcr-2018.

11. Iliev, I.D.; Funari, V.A.; Taylor, K.D.; Nguyen, Q.; Reyes, C.N.; Strom, S.P.; Brown, J.; Becker, C.A.; Fleshner, P.R.; Dubinsky, M. Interactions between commensal fungi and the C-type lectin receptor Dectin-1 influence colitis. Science 2012, 336, 1314-1317. [CrossRef] [PubMed]

12. Trojanowska, D.; Zwolinska-Wcislo, M.; Tokarczyk, M.; Kosowski, K.; Mach, T.; Budak, A. The role of Candida in inflammatory bowel disease. Estimation of transmission of C. albicans fungi in gastrointestinal tract based on genetic affinity between strains. Med. Sci. Monit. 2010, 16, CR451-CR457. [PubMed]

13. Zengin, G.; Menghini, L.; Malatesta, L.; De Luca, E.; Bellagamba, G.; Uysal, S.; Aktumsek, A.; Locatelli, M. Comparative study of biological activities and multicomponent pattern of two wild Turkish species: Asphodeline anatolica and Potentilla speciosa. J. Enzym. Inhib. Med. Chem. 2016, 31 (Suppl. S1), 203-208. [CrossRef]

14. Rodriguez-Delgado, M.; Malovana, S.; Perez, J.; Borges, T.; Montelongo, F.G. Separation of phenolic compounds by high-performance liquid chromatography with absorbance and fluorimetric detection. $J$. Chromatogr. A 2001, 912, 249-257. [CrossRef]

15. Recinella, L.; Chiavaroli, A.; Orlando, G.; Menghini, L.; Ferrante, C.; Di Cesare Mannelli, L.; Ghelardini, C.; Brunetti, L.; Leone, S. Protective Effects Induced by Two Polyphenolic Liquid Complexes from Olive (Olea europaea, mainly Cultivar Coratina) Pressing Juice in Rat Isolated Tissues Challenged with LPS. Molecules 2019, 24, 3002. [CrossRef] [PubMed]

16. Chiavaroli, A.; Recinella, L.; Ferrante, C.; Locatelli, M.; Carradori, S.; Macchione, N.; Zengin, G.; Leporini, L.; Leone, S.; Martinotti, S. Crocus sativus, Serenoa repens and Pinus massoniana extracts modulate inflammatory response in isolated rat prostate challenged with LPS. J. Biol. Regul. Homeost. Agents 2017, 31, 531-541. [PubMed]

17. Ferrante, C.; Orlando, G.; Recinella, L.; Leone, S.; Chiavaroli, A.; Di, C.N.; Shohreh, R.; Manippa, F.; Ricciuti, A.; Vacca, M. Central apelin-13 administration modulates hypothalamic control of feeding. J. Biol. Regul. Homeost. Agents 2016, 30, 883-888. 
18. Leone, S.; Chiavaroli, A.; Shohreh, R.; Ferrante, C.; Ricciuti, A.; Manippa, F.; Recinella, L.; Di Nisio, C.; Orlando, G.; Salvatori, R. Increased locomotor and thermogenic activity in mice with targeted ablation of the GHRH gene. Growth Horm. IGF Res. 2015, 25, 80-84. [CrossRef]

19. Livak, K.J.; Schmittgen, T.D. Analysis of relative gene expression data using real-time quantitative PCR and the $2^{-\Delta \Delta C}$ T method. Methods 2001, 25, 402-408. [CrossRef]

20. di Giacomo, V.; Ferrante, C.; Ronci, M.; Cataldi, A.; Di Valerio, V.; Rapino, M.; Recinella, L.; Chiavaroli, A.; Leone, S.; Vladimir-Knežević, S. Multiple pharmacological and toxicological investigations on Tanacetum parthenium and Salix alba extracts: Focus on potential application as anti-migraine agents. Food Chem. Toxicol. 2019, 133, 110783. [CrossRef]

21. Distler, A.M.; Kerner, J.; Peterman, S.M.; Hoppel, C.L. A targeted proteomic approach for the analysis of rat liver mitochondrial outer membrane proteins with extensive sequence coverage. Anal. Biochem. 2006, 356, 18-29. [CrossRef] [PubMed]

22. Ferrante, C.; Recinella, L.; Ronci, M.; Menghini, L.; Brunetti, L.; Chiavaroli, A.; Leone, S.; Di Iorio, L.; Carradori, S.; Tirillini, B. Multiple pharmacognostic characterization on hemp commercial cultivars: Focus on inflorescence water extract activity. Food Chem. Toxicol. 2019, 125, 452-461. [CrossRef] [PubMed]

23. Ferrante, C.; Recinella, L.; Ronci, M.; Orlando, G.; Di Simone, S.; Brunetti, L.; Chiavaroli, A.; Leone, S.; Politi, M.; Tirillini, B. Protective effects induced by alcoholic Phlomis fruticosa and Phlomis herba-venti extracts in isolated rat colon: Focus on antioxidant, anti-inflammatory, and antimicrobial activities in vitro. Phytother. Res. 2019, 33, 2387-2400. [CrossRef] [PubMed]

24. Charan, J.; Kantharia, N. How to calculate sample size in animal studies? J. Pharmacol. Pharmacother. 2013, 4, 303. [CrossRef] [PubMed]

25. Menghini, L.; Recinella, L.; Leone, S.; Chiavaroli, A.; Cicala, C.; Brunetti, L.; Vladimir-Knežević, S.; Orlando, G.; Ferrante, C. Devil's claw (Harpagophytum procumbens) and chronic inflammatory diseases: A concise overview on preclinical and clinical data. Phytother. Res. 2019, 33, 2152-2162. [CrossRef] [PubMed]

26. Menghini, L.; Ferrante, C.; Leporini, L.; Recinella, L.; Chiavaroli, A.; Leone, S.; Pintore, G.; Vacca, M.; Orlando, G.; Brunetti, L. An hydroalcoholic chamomile extract modulates inflammatory and immune response in HT29 cells and isolated rat colon. Phytother. Res. 2016, 30, 1513-1518. [CrossRef]

27. Banaganapalli, B.; Mulakayala, C.; Gowsia, D.; Mulakayala, N.; Pulaganti, M.; Shaik, N.A.; Anuradha, C.; Rao, R.M.; Al-Aama, J.Y.; Chitta, S.K. Synthesis and biological activity of new resveratrol derivative and molecular docking: Dynamics studies on NFkB. Appl. Biochem. Biotechnol. 2013, 171, 1639-1657. [CrossRef]

28. Chiavaroli, A.; Brunetti, L.; Orlando, G.; Recinella, L.; Ferrante, C.; Leone, S.; Di Michele, P.; Di Nisio, C.; Vacca, M. Resveratrol inhibits isoprostane production in young and aged rat brain. J. Biol. Regul. Homeost. Agents 2010, 24, 441.

29. Shanmuganathan, S.; Angayarkanni, N. Chebulagic acid Chebulinic acid and Gallic acid, the active principles of Triphala, inhibit TNF $\alpha$ induced pro-angiogenic and pro-inflammatory activities in retinal capillary endothelial cells by inhibiting p38, ERK and NFkB phosphorylation. Vasc. Pharmacol. 2018, 108, 23-35. [CrossRef]

30. Fiebich, B.L.; Muñoz, E.; Rose, T.; Weiss, G.; McGregor, G.P. Molecular targets of the antiinflammatory Harpagophytum procumbens (devil's claw): Inhibition of TNF $\alpha$ and COX-2 gene expression by preventing activation of AP-1. Phytother. Res. 2012, 26, 806-811. [CrossRef]

31. Lin, Y.-C.; Huang, D.-Y.; Chu, C.-L.; Lin, W.-W. Anti-inflammatory actions of Syk inhibitors in macrophages involve non-specific inhibition of toll-like receptors-mediated JNK signaling pathway. Mol. Immunol. 2010, 47, 1569-1578. [CrossRef] [PubMed]

32. Zuo, T.; $\mathrm{Ng}$, S.C. The gut microbiota in the pathogenesis and therapeutics of inflammatory bowel disease. Front. Microbiol. 2018, 9, 2247. [CrossRef] [PubMed]

33. Nazareth, N.; Magro, F.; Machado, E.; Ribeiro, T.G.; Martinho, A.; Rodrigues, P.; Alves, R.; Macedo, G.N.; Gracio, D.; Coelho, R. Prevalence of Mycobacteriumavium subsp. paratuberculosis and Escherichia coli in blood samples from patients with inflammatory bowel disease. Med. Microbiol. Immunol. 2015, 204, 681-692. [CrossRef] [PubMed]

34. Almeida, M.; Soares, S.; Abreu, P.; Jesus, L.; Brito, L.; Bernardo-Filho, M. Protective effect of an aqueous extract of Harpagophytum procumbens upon Escherichia coli strains submitted to the lethal action of stannous chloride. Cell. Mol. Biol. 2007, 53, OL923-OL927. 
35. Weckesser, S.; Engel, K.; Simon-Haarhaus, B.; Wittmer, A.; Pelz, K.; Schempp, C.Á. Screening of plant extracts for antimicrobial activity against bacteria and yeasts with dermatological relevance. Phytomedicine 2007, 14, 508-516. [CrossRef]

36. Betts, J.W.; Wareham, D.W.; Haswell, S.J.; Kelly, S.M. Antifungal synergy of theaflavin and epicatechin combinations against Candida albicans. J. Microbiol. Biotechnol. 2013, 23, 1322-1326. [CrossRef]

37. Bottari, N.B.; Lopes, L.Q.S.; Pizzuti, K.; dos Santos Alves, C.F.; Corrêa, M.S.; Bolzan, L.P.; Zago, A.; de Almeida Vaucher, R.; Boligon, A.A.; Giongo, J.L. Antimicrobial activity and phytochemical characterization of Carya illinoensis. Microb. Pathog. 2017, 104, 190-195. [CrossRef]

38. de Camargo, A.C.; Regitano-d'Arce, M.A.B.; Rasera, G.B.; Canniatti-Brazaca, S.G.; do Prado-Silva, L.; Alvarenga, V.O.; Sant'Ana, A.S.; Shahidi, F. Phenolic acids and flavonoids of peanut by-products: Antioxidant capacity and antimicrobial effects. Food Chem. 2017, 237, 538-544. [CrossRef]

39. Orlando, G.; Zengin, G.; Ferrante, C.; Ronci, M.; Recinella, L.; Senkardes, I.; Gevrenova, R.; Zheleva-Dimitrova, D.; Chiavaroli, A.; Leone, S. Comprehensive Chemical Profiling and Multidirectional Biological Investigation of Two Wild Anthemis Species (Anthemis tinctoria var. Pallida and A. cretica subsp. tenuiloba): Focus on Neuroprotective Effects. Molecules 2019, 24, 2582. [CrossRef]

40. Detienne, G.; De Haes, W.; Mergan, L.; Edwards, S.L.; Temmerman, L.; Van Bael, S. Beyond ROS clearance: Peroxiredoxins in stress signaling and aging. Ageing Res. Rev. 2018, 44, 33-48. [CrossRef]

41. Rashid, K.; Sinha, K.; Sil, P.C. An update on oxidative stress-mediated organ pathophysiology. Food Chem. Toxicol. 2013, 62, 584-600. [CrossRef] [PubMed]

42. Karachaliou, C.-E.; Kalbacher, H.; Voelter, W.; Tsitsilonis, O.E.; Livaniou, E. In Vitro immunodetection of prothymosin alpha in normal and pathological conditions. Curr. Med. Chem. 2019. [CrossRef]

43. Rocha-Perugini, V.; Gordon-Alonso, M.; Sánchez-Madrid, F. Role of Drebrin at the immunological synapse. In Drebrin; Springer: Berlin/Heidelberg, Germany, 2017; pp. 271-280.

44. Wang, G.-H.; Wang, J.-J.; Yue, B.; Du, X.; Du, H.-H.; Zhang, M.; Hu, Y.-H. High mobility group box 2 of black rockfish Sebastes schlegelii: Gene cloning, immunoregulatory properties and antibacterial effect. Fish Shellfish Immunol. 2019, 84, 719-725. [CrossRef] [PubMed]

45. Wu, W.; Chen, J.; Ding, Q.; Yang, S.; Wang, J.; Yu, H.; Lin, J. Function of the macrophage-capping protein in colorectal carcinoma. Oncol. Lett. 2017, 14, 5549-5555. [CrossRef] [PubMed]

46. Grimm-Günter, E.-M.S.; Revenu, C.; Ramos, S.; Hurbain, I.; Smyth, N.; Ferrary, E.; Louvard, D.; Robine, S.; Rivero, F. Plastin 1 binds to keratin and is required for terminal web assembly in the intestinal epithelium. Mol. Biol. Cell 2009, 20, 2549-2562. [CrossRef] [PubMed]

47. Kawaguchi, K.; Yoshida, S.; Hatano, R.; Asano, S. Pathophysiological roles of ezrin/radixin/moesin proteins. Biol. Pharm. Bull. 2017, 40, 381-390. [CrossRef]

48. Petchampai, N.; Sunyakumthorn, P.; Guillotte, M.L.; Verhoeve, V.I.; Banajee, K.H.; Kearney, M.T.; Macaluso, K.R. Novel identification of Dermacentor variabilis Arp2/3 complex and its role in rickettsial infection of the arthropod vector. PLoS ONE 2014, 9, e93768. [CrossRef]

(C) 2020 by the authors. Licensee MDPI, Basel, Switzerland. This article is an open access article distributed under the terms and conditions of the Creative Commons Attribution (CC BY) license (http://creativecommons.org/licenses/by/4.0/). 